\title{
The national forest inventory in China: history - results - international context
}

\author{
WeiSheng Zeng ${ }^{1 *}$, Erkki Tomppo ${ }^{2}$, Sean P. Healey ${ }^{3}$ and Klaus V. Gadow ${ }^{4,5,6}$
}

\begin{abstract}
Background: National forest resource assessments and monitoring, commonly known as National Forest Inventories (NFI's), constitute an important national information infrastructure in many countries.

Methods: This study presents details about developments of the NFI in China, including sampling and plot design, and the uses of alternative data sources, and specifically

- reviews the evolution of the national forest inventory in China through the 20th and 21st centuries, with some reference to Europe and the US;

- highlights the emergence of some common international themes: consistency of measurement; more efficient sampling designs; implementation of improved technology; expansion of the variables monitored; scientific transparency;

- presents an example of how China's expanding NFI exemplifies these global trends.

Results: Main results and important changes in China's NFI are documented, both to support continued trend analysis and to provide data users with historical perspective.

Conclusions: New technologies and data needs ensure that the Chinese NFI, like the national inventories in other countries, will continue to evolve. Within the context of historical change and current conditions, likely directions for this evolution are suggested.
\end{abstract}

Keywords: China; Europe; USA; National forest inventories; Forest inventory and analysis

\section{Background}

National forest resource assessment and monitoring, commonly known as National Forest Inventory (NFI), has become an important part of the national information infrastructure in many countries. NFI assessments provide an essential service, reconciling available resources with national priorities related to timeliness, precision, and forest values of interest. As a noun, the word 'inventory' refers to a detailed list of articles according to their properties with a commercial origin. As a verb, the word refers to the process of constructing that list. In a forest inventory, the tabulated information generally includes estimates for trees, tree properties and forests, often on the basis of areal units (Loetsch and Haller 1973; Davis et al. 2001; Tomppo et al. 2010b) and is regarded as reliable and adequate for its intended purposes.

\footnotetext{
* Correspondence: zengweisheng@sohu.com

${ }^{1}$ Academy of Forest Inventory and Planning, State Forestry Administration, Beijing 100714, China

Full list of author information is available at the end of the article
}

Additional demands, including information on forest ecosystem health, are constantly emerging and new technology is applied to meet these challenges. Internationally, there is great diversity regarding definitions, sampling designs, reporting protocols and error estimation. Definitions and specifications may also change over time in one country. Substantial efforts have been made to meet the new challenges. Forest health monitoring has become an essential part of the inventories in many countries. Properties include symptom description, causal agent, and degree of damage. Inventories have also added measurements and assessments of biodiversity indicators, such as dead and decaying wood and key habitats (Tomppo et al. 2010a). Collaborative projects to reach agreement on common definitions and to make inventory results comparable highlighted differences in FAO definitions (UNFCCC LULUCF COST Action E43 2015; Tomppo et al. 2010a; Lanz et al. 2010). The involvement of experts from both organizations made it possible to make good progress towards common definitions, e.g., in land class and carbon pool definitions. The adoption of new 
definitions takes time and needs to be coordinated with a new inventory round. A constant awareness and work of the harmonisation of the concepts as well as the use of common definitions is therefore necessary. Before the new definitions are really in use, some kind of intermediate tools may be needed (Ståhl et al. 2012).

The loss of forest cover and forest degradation, especially in many developing countries, has become a problem of international concern, particularly in view of global warming and high $\mathrm{CO}_{2}$ emissions (IPCC 2015). Inventories of land use and land use change, as well as biomass stock changes assessments, are integral tools in addressing these problems. The objective of this study is to describe the development of the national forest inventory in China, and to present the most recent estimates of the basic forest resource parameters, as well as the changes over time. Reference to forest resource inventories in some European countries, the FIA in the United States as well as the National Forest Assessment and Monitoring by FAO provides an international perspective.

\section{Development of NFI's in Europe}

The history of forest inventories dates back to the end of the Middle Ages when intensive use of forest resources first led to wood shortages which, in turn, forced users to assess timber resources, particularly near towns and mines (Loetsch and Haller 1973; Tomppo et al. 2010b). The first information collected for these purposes concerned forest area and crude estimates of growing stock.

The first inventories were often local with the aim of assessing the available timber resources for specific purposes and were often conducted by the timber users, e.g. commercial companies (Loetsch and Haller 1973; Davis et al. 2001). It soon became obvious that such inventories could not easily be used to compile national level forest information for purposes of formulating national forest policy; thus, NFIs were initiated.

Sample-based national forest inventories were initiated in the Nordic countries in the late 1910s and early 1920s, but were not introduced in other European countries until after World War II: in the late 1940s in the German Democratic Republic; in 1958 in France; in the 1960s in Austria; and in the 1980s in Switzerland. The early national inventories in the Nordic countries included not only information about areas, volume and increment of growing stock and the amount of timber, but also age, size and species structure of forests, silvicultural status of forests, accomplished and needed cutting and silvicultural regimes (Ilvessalo 1927). The purpose was to provide information for forest authorities, timber users, and planners who developed national forest policies. Some European countries have only recently introduced sample-based inventories. At the global level, national forest inventories are still lacking in many countries, although new inventories are being initiated all the time.

The sampling design in the first inventories in the three Nordic countries had some similarities and also some differences. All inventories used lines or strips passing through countries or country regions (Ilvessalo 1927; Tomppo et al. 2011). The intervals between the lines varied by regions depending on the variability of forests and land use. Norway and Sweden employed strip surveys: all trees over a certain diameter threshold were callipered on the strips with a width of $10 \mathrm{~m}$ (Tomter et al. 2010; Axelsson et al. 2010). The first NFI in Finland employed lines and visual assessment on the lines as well sample plots with exact mesurements and also with visual assessments on the plots, the latter one to calibrate the visual assessments (Ilvessalo 1927; Tomppo et al. 2011). All three countries changed the sampling designs later to utilize clusters of plots: Norway and Sweden in their inventories in 1957-1964 and 1952-1964, respectively, and Finland in the fifth inventory in 1964-1970. All inventories used only temporary plots first and later either a combination of permanent and temporary plots or only permanent plots. The Norwegian and Swedish NFIs have used fixed radius plots while the Finnish NFI angle count plots from 1964 until 2013. Concentric plots with two radii were adopted in the Finnish NFI in 2014.

Lawrence et al. (2010) gives a concise summary of the sampling designs in European countries and also in countries contributing the European Cost Action E43 and the country book written in the Action (Tomppo et al. 2011). Most of the countries use either detached field sample plots or clusters of plots. The forest area represented by one plot varied from 50 ha in Walloon region in Belgium and plantations in Iceland to 2400 ha in USA and 267,700 ha in Canada. There is quite a high diversity also in estimation methods, particularly in estimating the increment and the drain of trees. The country reports in the book by Tomppo et al. (2010a) presents more detailed descriptions of the inventory methods by countries and the changes in the designs.

New demands for forest inventories require timely and accurate spatially explicit information. Forest inventory groups have employed remotely sensed data for several decades to meet the requirements in a costeffective way, first using aerial photographs and later also satellite images (Spurr 1960). The increasing availability of aerial photography in digital form and the ease of integration with auxiliary and other georeferenced data (GIS data) has greatly facilitated the use of aerial photographs (McRoberts and Tomppo 2007). NFI country reports (Tomppo et al. 2010a) show that aerial photography is still widely used by European NFIs. Koch (2013) gives reasons for continued use of aerial photography, such as long traditions, high 
spatial resolution, greater probability of acquiring cloud free data within a specific time window as well as smaller areas and fragmented land use in European countries compared to, e.g., larger non-European countries such as the USA, Canada, or countries in South America.

The use of satellite images, based on NFI field data dates back to 1980, first for forest mapping in standlevel inventories in an experimental way and later operationally at the national level in Finland and Sweden, and increasingly for spatialisation and modeling in the 1990s and 2000s (Reese et al. 2003; Tomppo et al. 2008a), as well as for regional inventories in the USA (McRoberts et al. 2002; McRoberts 2012).

The current trend is to use multi-resolution and multisensor data in the inventories. Statistically sound methods, the development of which requires resources and time, are a priority. Detailed and comprehensive field data remains always as the core information in the national forest inventories. Another trend in Europe and elsewhere is to establish statistically sound sampling based inventories. For the reasons, see Section Evolution of FIA in the United States. The tight connections among the inventory teams worldwide maintain the harmonization of the definitions and the methods.

\section{Evolution of FIA in the United States}

A national forest inventory was established by the US Congress, through the McSweeney-McNary Act of 1928, to assess issues related to national and regional timber supply. For several decades, periodic forest assessments were completed on a state-by-state basis with little effort to create or enforce methodological standardization (U.S. Department of Agriculture 1992). Labau et al. (1992) provide an account of the changing techniques used by this inventory, which was called the country's "Forest Survey" for most of its history and has been called the Forest Inventory and Analysis program (FIA) since approximately 1990 (earlier in some quarters).

Prior to World War II, strip sample methods adapted from European designs, such as that used in Finland's general survey (Ilvessalo 1927), were common across the country. Timber measurements were taken at fixed distances along transects that were typically established along regular, parallel lines. Following the war, advances in aerial photogrammetry made more efficient stratified designs feasible, and strip sampling became less common (Labau et al. 1992). Starting around 1950, plots began to be sampled using "variable radius" plot cruising, based upon sampling proportional to tree size. These techniques were adapted in the US from work in Austria by Bitterlich (Grosenbaugh 1958). From approximately 1960 through the mid-1980s, most inventory units used a 10-point cluster design within a 0.405 ha ( 1 acre $)$ area. At the same time, programmable computers were making it possible to automate the calculation and tabling of volume estimates. This technology also supported compilation of data across many inventories, and in 1965, the USDA published what, according to Labau et al. (1992)), was the first truly nationwide forest survey report (U.S. Department of Agriculture 1965).

In addition to trends toward more efficient and more nationally consistent sampling and compilation, there were social and legislative developments that motivated the inventory to move beyond its roots in timber to assessment of a wider variety of forest resources. Public appreciation of non-timber forest resources such as water, habitat, and recreation use grew during the 1970s. The Forest and Rangeland Renewable Resources Planning Act of 1974 (RPA) broadened the mandate of the Forest Survey to include monitoring of a range of non-timber resources (U.S. Department of Agriculture 1992). Nontimber resource data from the inventory, such as habitat area estimates, informed several forest management debates, e.g., informed debates about management of public land (Bolsinger and Waddell 1993).

Several developments during the 1990s led to standardization of inventory techniques and analysis methods across the country. Beginning in 1996, all plots were required to use a four-point design that incorporated sampling proportional to plot area instead of tree size (Labau et al. 1992). Over the subsequent decade, all states migrated to a nationally consistent sample framework, in which one permanent plot was situated randomly within each 2430-ha (6000-acre) cell of a hexagonal tessellation of the country. This sample design is considered to be a "spatially balanced simple random sample," ensuring good geographic distribution of points while retaining a stochastic element (Reams et al. 2005). The sample can be intensified in areas of interest by further tesselating existing hexagons into finer spatial units, each with a randomly located sample. A national "core" set of variables is measured at each plot, and there is flexibility to add measurements to address regionally important monitoring questions. Until approximately 2010, additional measurements, focused primarily on forest health, were collected on $1 / 16$ of all plots to allow broad-scale assessment of covered variables. Since then, a few of these variables have been moved to "core" status (measured on all plots), and the rest have been retired.

Plots are measured on a rotating basis in such a way that an approximately equal number of plots per state is measured each year. The re-measurement cycle is $5-10$ years, depending upon the state, and because $10-20 \%$ of the grid is visited each year, the system is known as an "annual inventory", as opposed to the earlier practice of periodically measuring all plots in the same year. As a result, instead of a single-date snapshot of conditions that becomes more 
dated until the next re-measurement, FIA estimates reflect a rolling average picture of conditions over a 5- to 10-year period.

A principle of the inventory of FIA (and other NFI's) is the focus on supporting a wide range of academic, industrial, governmental, and environmental clients. Reports on forest status and trends are published at both the state and national levels every 5 years. The national report (Smith et al. 2009) is considered the authoritative description of the US forestry sector. Beyond those reports, the public accesses the database itself approximately 100,000 times per year (U.S. Department of Agriculture 2015). While the exact coordinates of the plots are not publically available to protect the integrity of the sample (Healey et al. 2011), the local neighborhood of each plot is provided, as are all other elements of the plot measurements. This policy of availability is thought to maximize the return on the national investment in the inventory. NFIs vary in their willingness to share data beyond aggregate statistics. Outside of the free data access model pursued by the US and other countries, many NFIs share plot information only with select collaborators, while others, including China in the past, carefully restrict data access.

Today, sample-based inventories are conducted in most European and North American countries, although the tradition in Eastern Europe has been to aggregate data from stand-level inventories originally designed for management planning purposes. Stand level data are often assessed in different years and error estimation of such national aggregates are not possible. Consequently, many Eastern European countries have recently revised their systems in favour of statistical, sample-based NFIs. The main reason is to conduct and maintain forest inventories within a statistical framework presenting timely information and making it possible to estimate uncertainties of forest resource parameters. The Country reports in Tomppo et al. (2010a) give an overview of these changes by countries.

\section{FAO NFMA}

Since the early 2000s, the Forestry Department of the Food and Agriculture Organization of the United Nations (FAO) has invested substantial resources in developing a programme of support to national forest monitoring and assessment, commonly known as NFMA (Saket et al. 2010; FAO 2013; Tomppo et al. 2014). The NFMA operates mainly in developing countries, particularly in Tropical forests, and technical, financial, and institutional co-operation and support is often needed. Saket et al. (2010) characterized the NFMA approach as follows:

- Demand driven: countries request FAO support and define the assessment scopes as well as information requirements.
- Participatory: the involvement of a wide range of stakeholders is encouraged, including government institutions, the private sector and NGOs.

- Harmonized: the terms and definitions are consistent among national institutions and refer to internationally agreed terms and definitions. The harmonization allows comparison between countries and facilitates reporting to international reporting processes.

According to Saket et al. (2010), the objective of the NFMA is "to contribute to the sustainable management of forests and trees outside forests by providing national decision makers and stakeholders with the means of acquiring accurate, relevant and cost-effective information on the state, uses, management of the forestry resources and land use changes. Such information is particularly relevant for national and international dialogue on forestry related policy issues and socio-economic development". For more detailed objectives, see Saket et al. (2010). Assessing trees outside forests may develop into one of the most important challenges for the immediate future.

By 2013, NFMA had been completed in 10 countries and was in progress or anticipated in another 20 countries (FAO 2013). FAO's NFMA had employed a standard approach regarding sampling design and data collection until 2009. The major sampling unit was a $1 \times 1 \mathrm{~km}$ square. Each unit contained a cluster of four plots with a size of $250 \times 20 \mathrm{~m}$, placed in perpendicular orientations. Small trees were measured on nested subplots. The details of the design are described by Saket et al. (2010) and FAO (2013). Due to the high workload for each cluster, the sampling intensity of the plots had been low. Estimates could have been computed on the national level only (Tomppo et al. 2014). However, when necessary, the sampling intensity was increased based on local information needs. FAO's NFMA has also launched specific studies to analyse and further develop the design based on local information needs (Tomppo and Katila 2008b; Tomppo et al. 2014). One aspect regarding inventories in Tropical countries isaccessibility,-the time needed to reach a field plot. Specific statistical methods are used to address this problem involving, for example, stratification. Considerations related especially to forest inventories in the Tropics are discussed by McRoberts et al. (2013).

\section{Methods}

\section{Brief history of NFI in China}

In China a national forest inventory was started relatively early. After the People's Republic of China was established in 1949, some national institutions for forest survey were set up at first in the northeastern region, and forest surveys were conducted in the Changbai Mountain and Xiaoxinganling forest areas. Subsequently, forest surveys 
were gradually extended all over the country. In 1962, the former Agriculture and Forestry Ministry (AFM) of China organized the provincial forestry departments to compile forest resource data from various inventories, such as reconnaissance surveys and forest management inventories conducted during the period 1950-1962 and prepared summaries for the whole country. For the first time in China forest resource data were gathered and reported for the country as a whole. This nation-wide assessment presented a general overview of forest resources in China. However, this first compilation of inventories only covered about 300 million ha, involving the main forest regions and State Forest Bureaus (Xiao 2005).

In 1973, the former AFM conducted two forest inventory pilot studies, one in northern China and another in southern China. Based on the findings, technical specifications on main methods in forestry surveys were issued. During 1973-1976, the first national forest inventory (NFI1), which is usually called the "4th 5-year Plan" Inventory, was implemented. Based on county-level inventories, the sampling designs and survey methods were not standardized for the whole country. In 1977, the former AFM conducted a pilot study involving a continuous forest inventory (CFI) in Jiangxi province. Based on findings of that pilot study, standard specifications on continuous forest inventory in China were issued for execution (AFM 1978).

During the period 1977-1981, the NFI2 was implemented, based on CFI principles with permanent plots and statistical sampling. The provinces, municipalities or autonomous regions, represented the target population. The basic sampling frame of the CFI system had become a good foundation for national forest inventory in China. Subsequently, a total of six NFIs (NFI3 to NFI8) were continuously conducted during the periods 1984-1988, 1989-1993, 1994-1998, 1999-2003, 2004-2008, and 2009-2013 (Xiao 2005; Lei et al. 2009; Lin et al. 2013). The key characteristics of the eight NFI's in China are listed in Table 1.

Following economic and technical advancement, the NFI system in China has been continually improved regarding sampling design, survey methods, and technical standards.

\section{Sampling design \\ Sample grid}

The history of NFI in China shows a progressive evolution towards statistical sampling techniques. All the provinces are now using a systematic sampling design and permanent field plots. For the purpose of efficiency, sampling designs should accommodate variation in forest attributes and land use structure, which suggests that the idea of a single design for the whole country may not be suitable. The most common NFI features include systematic sampling components based on two-dimensional grids, although the grid spacing varies considerably, from $1 * 2 \mathrm{~km}^{2}$ in Shanghai, $2 * 2 \mathrm{~km}^{2}$ in Beijing and Tianjin to $6 * 8 \mathrm{~km}^{2}$ in Yunnan and $8 *$ $8 \mathrm{~km}^{2}$ in Inner Mongolia (Table 2). A few provinces, such as Heilongjiang, Gansu, Qinghai and Xinjiang, divide the population into two or three strata according to ecogeographic regions. Each stratum is considered as an independent sub-population in which systematic sampling is applied. The inventory has a 5-year cycle, and about $1 / 5$ provinces conduct inventories each year. The sampling population of the NFI in China is the total land area, including inland water. Plots are established on non-forest land for purposes of estimating the area of lands converted from non-forest to forest uses and vice versa.

For the estimation of inventory statistics, the estimators and error estimators were based on an asummption of simple random sampling in most provinces. In provinces with sub-populations, the estimators and error estimators of stratified sampling were used where each sub-population was considered as a stratum. Simple random sampling was assumed within each stratum. The national statistics were obtained from the summation of all provincial statistics completed in a 5-year cycle, and the errors were estimated using stratified sampling where each province was considered as a stratum (SFA 2011).

\section{Plot configuration}

The shape, size and number of sample plots vary greatly among provinces. Square plots are used in more than $90 \%$ of the provinces. Circular plots are used only in Tibet, while rectangular plots are used in Inner Mongolia and in one sub-population of Heilongjiang. Point sampling or angle count sampling was used in Guangxi before the 6th NFI, but square plots have been used since 2005 (Cen et al. 2007). In the past, several provinces such as Henan and Hubei used to apply cluster sampling in plateau areas, where a cluster was composed of 4 or 5 plots (Xiao 2005).

Plot sizes vary between 0.06 and 0.10 ha, and most of them are 0.0667 ha ( 1 Chinese $m u$ ). Among the 31 provinces in China (not including Taiwan, Hongkong and Macao, the same hereafter), the smallest sample numbers are less than 3000 (Jiangxi 2608, Tianjin 2818, and Hainan 2829). The greatest number of samples exceeds 10,000 (Inner Mongolia 17,951, Hebei 11,709, Anhui 11,678, Henan 10,358, and Sichuan 10,007). For most of the provinces, the number of sample plots are between 3000 and 10,000. Several provinces had more sample plots before. For example, the number of sample plots in Guizhou was 11,017 before 1995, about twice the present number, while the sample in Jiangxi was 10,455 before 1996, about four times the current number of sample plots (Xiao 2005). Since the 6th NFI, the sampling design of each province did not change. The number, shape and size of sample plots for 31 provinces are summarized in the Table 2. 
Table 1 Key characteristics of the eight NFIs in China

\begin{tabular}{|c|c|c|}
\hline NFIs & Period & Key characteristics \\
\hline $\mathrm{NFI1}$ & 1973-1976 & $\begin{array}{l}\text { Based on county-level inventory, in most regions the inventory was not unified for } \\
\text { the whole country }\end{array}$ \\
\hline $\mathrm{NFI} 2$ & 1977-1981 & $\begin{array}{l}\text { The continuous forest inventory (CFI) method was applied, establishing an effective } \\
\text { foundation for national monitoring }\end{array}$ \\
\hline $\mathrm{NFI3}$ & 1984-1988 & $\begin{array}{l}\text { The 1st re-inventory based on the CFI system, providing the changes on both quantity } \\
\text { and quality of forest resources }\end{array}$ \\
\hline NFI4 & 1989-1993 & $\begin{array}{l}4 \text { national forest monitoring centers were set up, which were responsible for quality check, } \\
\text { statistical compilation, and output reporting for different regions }\end{array}$ \\
\hline $\mathrm{NFI5}$ & 1994-1998 & $\begin{array}{l}\text { The UNDP CPR 91/151 project was executed, and new technologies such as "3S" } \\
\text { (RS-remote sensing, GPS-global positioning system, GIS-geographic information system) were started }\end{array}$ \\
\hline NFI6 & 1999-2003 & Remote sensing was widely applied, and full-coverage inventory for the mainland of China was achieved \\
\hline $\mathrm{NFI7}$ & 2004-2008 & Several ecological variables were added, and forest ecological services in the whole country were evaluated \\
\hline $\mathrm{NFI}$ & 2009-2013 & Modeling of tree biomass equations for main tree species in China has been actively pursued \\
\hline
\end{tabular}

It should be pointed out that some provinces in western China base their inventories partially on interpretation plots using satellite imagery, such as LandSat, SPOT and RapidEye. For remote or inaccessible regions, interpretation of image plots represents the only information obtained. For example, about $30 \%$ of forest plots had to be assessed through interpretation of image plots in Tibet.

\section{Field survey methods}

Field surveys represent the key activities of the NFI, relating directly to the subsequent statistical analysis and inventory outputs. A field survey usually involves three aspects: survey items, survey procedures and survey methods. Survey items (also called "variables" here) are defined by the technical specification. According to the newest Technical Specifications on National Continuous Forest Inventory issued for excution in 2014, the survey items include land use and cover, site and soil, forest stand characteristics, forest functions, ecological situations, species names and other items (SFA 2014a). Survey procedures generally involve plot location and establishment, survey of tree attibutes and plot attributes. In China's NFI, all plots are located on the kilometer grids of topographic maps $1: 50,000$ or $1: 100,000$, and should be permanently marked and periodically revisited. The survey of tree and plot attributes involves two different methods, measurement and judgement.

\section{Quantitative measurement}

The most important quantitative attibute is the diameter at breast height (dbh) of sample trees, which is measured using a diameter tape. The breast height is defined as $1.3 \mathrm{~m}$, and the minimum dbh is $5.0 \mathrm{~cm}$ measured over bark. The maximum allowable measurement error (tolerance) for dbh measurement is $3 \mathrm{~mm}$ or $1.5 \%$ (for trees with a dbh exceeding $20 \mathrm{~cm}$ ).

The second most important quantitative tree attibute is height, which is measured using a traditional clinometer or ultrasonic hypsometer. The height of small trees can be measured using a wooden or bamboo stick, or even a fishing rod. The tolerance for tree height measurement is $3 \%$ (for trees less than $10 \mathrm{~m}$ ) or $5 \%$ (for tree heights exceeding $10 \mathrm{~m}$ ). In China's NFI, height measurements are only required for 3-5 average trees on each forest plot (SFA 2014a).

Besides dbh and tree height, other quantitative attibutes, including azimuth and horizontal distance from the plot center to the sample tree, are measured usually using a box compass. In addition, crown cover (or crown closure, canopy cover, canopy closure) of a forest stand need to be measured using transect sampling with two diagonal lines or cover area estimation based on mean crown width. Sometimes, crown cover is measured using visual estimation or subjective judgement, based on the experience of the cruising team.

\section{Qualitative assessments}

Most of tree and plot attributes are assessed using qualitative judgement. The qualitative attributes are usually classified into several classess, groups, or grades. Land type and forest category are two of the most important plot attributes. Land is classified into two types: forest land and non-forest land. Forest land and non-forest land are both divided into 5 classes (Table 3). Some of these can be divided further.

Forests are also classified into five categories related to administrative use: protection forest, special use forest, timber forest, fuel-wood forest, and economic forest. The first two categories are called "ecological forests", while the remaining three categories are known as "commercial 
Table 2 Sampling designs for 31 provinces in China's NFI

\begin{tabular}{|c|c|c|c|c|c|c|c|}
\hline Provinces & Sub-pop. & Area: $\mathrm{km}^{2}$ & number of Plots & Grid $(\mathrm{Km})$ & Plot shape & Plot size (ha) & Year of last inventory \\
\hline Beijing & 1 & 16,410 & 4074 & $2 * 2$ & Square & 0.0667 & 2011 \\
\hline Tianjin & / & 11,305 & 2818 & $2 * 2$ & Square & 0.0667 & 2012 \\
\hline Hebei & / & 187,693 & 11,709 & $4 * 4$ & Square & 0.06 & 2011 \\
\hline Shanxi & / & 156,623 & 9915 & $4 * 4$ & Square & 0.0667 & 2010 \\
\hline Inner Mongolia & / & $1,183,000$ & 17,951 & $8 * 8$ & Rectangular & 0.06 & 2013 \\
\hline Liaoning & / & 145,739 & 4613 & $4 * 8$ & Square & 0.08 & 2010 \\
\hline $\mathrm{Jilin}^{\mathrm{a}}$ & / & 189,193 & 8865 & $4 * 16 / 3$ & Square & 0.06 & 2009 \\
\hline \multirow[t]{3}{*}{ Heilongjiang } & । & 100,540 & 1571 & $8 * 8$ & Square & 0.06 & 2010 \\
\hline & $\|$ & 64,786 & 1013 & $8 * 8$ & Rectangular & 0.06 & 2010 \\
\hline & III & 289,282 & 9083 & $4 * 8$ & Square & 0.06 & 2010 \\
\hline Shanghai & / & 6341 & 3365 & $2 * 1$ & Square & 0.0667 & 2009 \\
\hline Jiangsu & / & 102,600 & 8536 & $4 * 3$ & Square & 0.0667 & 2010 \\
\hline Zhejiang & / & 101,800 & 4249 & $4 * 6$ & Square & 0.08 & 2009 \\
\hline Anhui & / & 138,165 & 11,678 & $4 * 3$ & Square & 0.0667 & 2009 \\
\hline Fujian & / & 121,501 & 5051 & $4 * 6$ & Square & 0.0667 & 2013 \\
\hline Jiangxi & / & 166,946 & 2608 & $8 * 8$ & Square & 0.0667 & 2011 \\
\hline Shandong & / & 152,221 & 9646 & $4 * 4$ & Square & 0.0667 & 2012 \\
\hline Henan & / & 167,000 & 10,358 & $4 * 4$ & Square & 0.08 & 2013 \\
\hline Hubei & / & 185,900 & 5820 & $4 * 8$ & Square & 0.0667 & 2009 \\
\hline Hunan & / & 211,835 & 6615 & $4 * 8$ & Square & 0.0667 & 2009 \\
\hline Guangdong & / & 176,769 & 3685 & $6 * 8$ & Square & 0.0667 & 2012 \\
\hline Guangxi & / & 237,600 & 4948 & $6 * 8$ & Square & 0.0667 & 2010 \\
\hline Hainan & / & 33,907 & 2829 & $4 * 3$ & Square & 0.0667 & 2013 \\
\hline Chongqing & / & 82,335 & 5133 & $4 * 4$ & Square & 0.0667 & 2012 \\
\hline Sichuan & I & 483,744 & 10,007 & $6 * 8$ & Square & 0.0667 & 2012 \\
\hline Guizhou & / & 176,167 & 5500 & $4 * 8$ & Square & 0.0667 & 2010 \\
\hline Yunnan & / & 382,644 & 7891 & $6 * 8$ & Square & 0.0667 & 2012 \\
\hline Tibet & / & $1,228,436$ & ${ }^{a} 5855$ & $6 * 8$ & Circular & 0.0667 & 2011 \\
\hline Shaanxi & / & 205,977 & 6440 & $4 * 8$ & Square & 0.08 & 2009 \\
\hline \multirow[t]{3}{*}{ Gansu } & I & 449,734 & 2817 & $2 * 3$ & Square & 0.08 & 2011 \\
\hline & $\|$ & & 4038 & $3 * 3$ & Square & 0.08 & 2011 \\
\hline & III & & 10,846 & $4 * 8$ & Square & 0.08 & 2011 \\
\hline \multirow[t]{2}{*}{ Qinghai } & 1 & 721,514 & 76,616 & $2 * 2$ & Square & 0.08 & 2013 \\
\hline & $\|$ & & 51,620 & $4 * 2$ & Square & 0.08 & 2013 \\
\hline Ningxia & / & 51,955 & 12,936 & $2 * 2$ & Square & 0.06 & 2010 \\
\hline \multirow[t]{2}{*}{ Xinjiang } & I & 164,700 & 16,474 & $3 * 4$ & Square & 0.08 & 2011 \\
\hline & $\|$ & & 59,917 & $6 * 4$ & Square & 0.08 & 2011 \\
\hline
\end{tabular}

${ }^{a}$ The permanent plots in Jilin province were established through intensifying the $4 * 8 \mathrm{~km}$ grid by $50 \%$, that is, there are 3 plots for each $64 \mathrm{~km}{ }^{2}$ square. The number of plots (5855) in Tibet only includes the ground plots in the 1st sub-population (30 forestry counties). The number of plots in Gansu, Qinghai, Ningxia and Xinjiang include some RS-interpretation plots, as supplement to ground plots. Taiwan, Hongkong and Macao are not included in this table

forests". The definition of forest in China's NFI has changed to some extent during different periods. Before 1994, the minimum crown cover of a forest stand was 0.4 (or $35 \%$ ); but since the 5th NFI in 1994-1998, the minimum crown cover is defined as $20 \%$. In addition, since the 6th NFI, forests not only include arboreal forests and bamboo forests with a crown cover of more than $20 \%$, and economic shrubs with a crown cover of more than $30 \%$ which provide mainly non-wood forest products and fruits, but also include other special shrubs, which are defined as shrub 
Table 3 Land Classification System

\begin{tabular}{|c|c|c|}
\hline \multicolumn{2}{|l|}{ Class name } & \multirow{2}{*}{$\begin{array}{l}\text { Description } \\
\text { Forest land with a minimum area of } 667 \mathrm{~m}^{2} \text {, a minimum width of } 10 \mathrm{~m} \text {, } \\
\text { and a minimum crown cover of tree species of } 20 \%\end{array}$} \\
\hline Forest land & Arboreal forest & \\
\hline & Bamboo forest & Forest land composed of bamboos with a minimum dbh of $2 \mathrm{~cm}$ \\
\hline & Open forest land & Forest land with a crown cover of tree species of 10-19\% \\
\hline & Shrub land & $\begin{array}{l}\text { Forest land with a minimum crown cover of shrub species of } 30 \% \text {, } \\
\text { including two sub-classes: special shrubs and general shrubs }\end{array}$ \\
\hline & Other forest land & $\begin{array}{l}\text { Unclosed afforestation land, nursery land, clear-cut land, burned forest land, } \\
\text { and planned forest land }\end{array}$ \\
\hline \multirow[t]{5}{*}{ Non-forest land } & Cropland & Cultivated land, farmland \\
\hline & Grazing land & Pasture, rangeland, grassland \\
\hline & Inland water & Lakes, rivers, and other water bodies \\
\hline & Built-up land & $\begin{array}{l}\text { Industry and commerce, mining, traffic and transport, tourist facilities, } \\
\text { dwellings and parking sites, gardens and parks }\end{array}$ \\
\hline & Other land & Unused and unproductive non-forest land \\
\hline
\end{tabular}

lands located above the tree lines or in the area with less than $400 \mathrm{~mm}$ precipitation, or located in the karst region or dry-hot valley areas (SFA 2014a).

Other forest characteristics include origin, dominant species, age class/group, community structure, species composition, naturalness, disaster class, health class and so on. Forests are classified into two classes by origin: natural forests and plantations. They are also classified into five classes by age category: young, middle-aged, near-mature, mature, and post-mature forests. The details of definitions and specifications of all qualitative attributes can be found in SFA (2014a).

\section{New technology}

Remote sensing

The application of remote sensing (RS) in forest inventory can be traced back to early years of new China. The middle of the 1950s was the first time in China that aerial forest surveys and comprehensive ground investigations were implemented. Then, a technical system for forest inventory was established which was based on aerial photography and visual measurement. In the NFI1, remote sensing played an important role. At that time, the remotely sensed data were aerial photos. In the NFI2, remote sensing was applied to forest inventory of Tibet in 1977. Black-and-white MSS images of 1:500,000 scale and aerial photos of small scale were used to determine forest area. In the NFI3, the application of remote sensing was less important. In inaccessible regions in some provinces in western China, remotely sensed data was used as supplement of field survey. In the NFI4, remote sensing was applied to forest inventory of Tibet again in 1991, where Landsat TM images were used to interpret forest area, and field plots were measured to obtain forest volume per hectare. In NFI5, combining with the implementation of UNDP CPR 91/151 project, double sampling for stratification based on remote sensing interpretation and ground survey was tested in the Jiangxi pilot in 1996, which settled a technical foundation for wide application of remote sensing. In NFI6, remote sensing was widely used in all of the 31 provinces. Several provinces in western China, such as Tibet, Xinjiang, Gansu, Qinghai and Sichuan, conducted firstly their full-coverage inventories based on remote sensing (Zeng 2004; Wang et al. 2005; Zhang and Wang 2007). In the 7th and 8th NFIs, remote sensing continued to be appllied as an effective supplement to ground plots and an important information source for forest mapping. During this period, integrated application of multi-scale remotely sensed data has been taken into consideration.

\section{GPS and other technologies}

Global positioning systems (GPS) have been applied to forest inventory for less than 20 years in China. In the NFI5, combining with the implementation of UNDP CPR 91/151 project, the application of GPS in NFI was first tested in the Jiangxi pilot in 1996. In the NFI6, GPS was gradually applied to field survey in several provinces (Luo et al. 2002). Since the 7th and 8th NFIs, GPS techniques have been widely used in field work of NFI in all 31 provinces. Using the functions of positioning and navigation decreases the time for locating plots, increases the ratio of re-measured plots, and provides assurance in some extent to increase the quality of inventory data (Luo et al. 2002; Wu and Jiang 2006).

Besides RS and GPS, additional new technologies include advanced database applications and modeling, and the use of portable digital assistants (PDA/i-pad) and geographical information systems (GIS). Statistics and calculations mainly depended on manual work, or were supported to some extent by calculator and simple 
computer before the NFI4. During the NFI4 in 19891993, normative database files based on dBase and BASIC started to be applied in the office work. In the NFI5, mini-type of database based on Foxplus was used. Since theNFI6, large database based on Oracle has been applied, which can ensure security and stability of NFI data, and increase the efficiency of data processing and information management.

Modeling techniques were only used for establishment of tree volume equations between NFI1 and NFI4. In NFI5 (1994-1998), the application of growth and yield models was used in the Jiangxi pilot, with the implementation of UNDP CPR 91/151 project. Since NFI6, modeling techniques have been widely used for estimation of growth and drain (including cut and dead volume) (SFA 2011). During NFI8, specific modeling techniques were been applied to develop biomass equations for the main tree species in China (Zeng 2011, 2014, 2015).

The first pilot of PDA application was made in Tianjin in 2002. Since NFI7, PDA techniques have been used in several provinces, especially in north-eastern China (Wang 2006). In recent years, data collection system based on i-pad has started to be applied in NFI (Xiao et al. 2013). Application of PDA/i-pad system in NFI can achieve paper-free data collection, increase the accuracy of data, and strengthen the pertinence of quality control (Zhang and Zhang 2008). However, because of the disadvantages of poor waterproof capability, less battery life, small memory space, and limited CPU processing ability, PDA is still not applied to NFI in most provinces, especially in southern China.

The application of GIS (geographical information system) in NFI was relatively late. In NFI5, combining with the implementation of UNDP CPR 91/151 project, the application of GIS in was first tested in the Jiangxi pilot, which laid a foundation for wide application of GIS in NFI. Since NFI6, GIS techniques have been widely used in NFI, providing a technical platform for management of inventory data, querying and analysis of spatial data, and increasing the quality and efficiency of forest mapping (Wang and Li 2010; Shu 2014).

\section{Results and Discussion}

\section{Forest area and growing stock volumes}

According to the results of NFI8 in 2009-2013, the total forest area in China is 207.69 million hectares, the relative forest cover is estimated at $21.63 \%$, and the total growing stock volume at 15.14 billion $\mathrm{m}^{3}$ (SFA 2014b). Estimates of forest area, forest cover percent and growing stock volume from NFI1 to NFI8 are listed in Table 4. Forest area, forest cover percent and growing stock volume show continuous increase, except from NFI1 to NFI2, due to large scale afforestation and strict natural forest protection.
As mentioned before, the original definition of forest in China's NFI has changed somewhat during different inventory periods. Thus, the values of the forest areas in Table 4 are not completely comparable. Figure 1 shows the resulting differences of forest areas, using three independent time series and the published total.

In addition, there are other factors affecting the comparability between different measurement occasions, such as improved sampling and progress in remote sensing. For example, during the three decades from NFI1 to NFI6, only three inventories were conducted in Tibet, and the results were not completely comparable. Tibet is an autonomous region with extensive forest areas, the highest growing stock volumes and a low population density. Thus, the forest area and growing stock volumes are relatively stable. But during three inventories in 1977, 1991 and 2001, the forest area has increased from 6.32, 7.17 to 8.45 million ha, and the growing stock volume increased from 1.40 to 2.05 and 2.27 billion $\mathrm{m}^{3}$. The increase of forest area and growing stock volume in Tibet amounts to 0.85 million ha and 0.65 billion $\mathrm{m}^{3}$ respectively from NFI3 to NFI4, representing 9 and $65 \%$ of the total increase of forest area and volume in the whole country. The specific inventory results of other provinces, such as Sichuan, also influenced the comparability of national statistics between different inventory periods.

\section{Forest types, origins and age classes Forest types}

Forests include three types: arboreal forests, bamboo forests, and special shrubs. Among the total forest area, arboreal forests are 175.34 million ha (not including 2.13 million ha forests in Taiwan, Hongkong and Macao), bamboo forests are 6.01 million ha, and special shrubs are 24.21 million ha. Forests are further classified into 5 categories, i.e., protective forest, special-use forest, timber forest, fuelwood forest, and economic forest, which are respectively 99.67, 16.31, $67.24,20.57,1.77$ million ha (SFA 2014b). The areas and proportions of different forest categories from NFI1 to NFI8 in China are listed in Table 5 (Lei 2005; SFA 2009, 2014b).

Table 5 shows that the proportions of protective forest and special-use forest are increasing gradually from NFI1 to NFI8 while those of timber forest and fuelwood forest are decreasing. The changes from NFI5 to NFI7 are especially obvious, reflecting the strategic shift in China's forest policy from timber production to ecological conservation at the turn of the century. The proportion of econmic forest increases gradually from NFI1 to NFI5 but decreases slightly from NFI5 to NFI8 which is the result of the market share of fruits and other non-timber forest products reaching close to saturation levels. 
Table 4 Forest area, forest cover percent and growing stock volume of the eight NFIs in China

\begin{tabular}{lrrr}
\hline NFIs & $\begin{array}{c}\text { Forest area } \\
\text { (million ha) }\end{array}$ & $\begin{array}{c}\text { Forest cover } \\
\text { percent (\%) }\end{array}$ & \multicolumn{2}{c}{$\begin{array}{l}\text { Growing stock volume } \\
\text { (billion ha) }\end{array}$} \\
\hline NFI1 & 121.86 & 12.69 & 8.66 \\
NFI2 & 115.28 & 12.01 & 9.03 \\
NFI3 & 124.65 & 12.98 & 9.14 \\
NFI4 & 133.70 & 13.92 & 10.14 \\
NFI5 & 158.94 & 16.55 & 11.27 \\
NFI6 & 174.91 & 18.21 & 12.46 \\
NFI7 & 195.45 & 20.36 & 13.72 \\
NFI8 & 207.69 & 21.63 & 15.14 \\
\hline
\end{tabular}

\section{Forest origins}

Forests are classified into two main types: natural forests and plantations. In the traditional concepts in China's NFI, natural forests and plantations do not include other special shrubs except economic shrubs. According to the results of NFI8, the area and growing stock volume of natural forests amount to 121.84 million ha and 12.30 billion $\mathrm{m}^{3}$ respectively, while those of plantations are 69.33 million ha and 2.48 billion $\mathrm{m}^{3}$ (SFA 2014b).

Most of the forests in China are natural forests occupying $64 \%$ of the total forest area and $83 \%$ of the total growing stock volume respectively. Looking at the results of previous NFIs, we find that the plantation area and volume proportions gradually increase from 20 and $2 \%$ in NFI1 to 36 and $17 \%$ in NFI8 (Table 6). This increase is mainly due to the extensive afforestations during the past decades.

\section{Forest age classes}

Forests, excepting bamboo and economic forests, are classified into five age classes: young, middle-aged, near-mature, mature, and over-mature forests. According to the results of NFI8, the area and volume of young forests are 53.32 million ha and 1.63 billion $\mathrm{m}^{3}$ respectively. Those of middle-aged forests are 53.11 million ha and 4.11 billion $\mathrm{m}^{3}$, and those of near-mature, mature, and overmature forests are respectively 58.17 million ha and 9.04 billion $\mathrm{m}^{3}$ (SFA 2014b).

The majority of the forests in China are young and middle-aged, occupying $65 \%$ of the total forest area. The results of previous NFIs show that the proportions of area and volume of forests in two age classes are relatively constant (Table 7 ). The young and middle-aged forests occupy about $2 / 3$ of the area and less than $40 \%$ of the total volume, and the mature forests occupy about $1 / 3$ of the area and more than $60 \%$ of the volume.

\section{Increment and drain}

The increment estimated by China's NFI is defined as the volume increment of survivor trees between two inventory periods plus half of the volume increment of harvested or dead trees and the volume of ingrowth trees that exceed the dbh-threshold of $5.0 \mathrm{~cm}$ between the two inventories (SFA 2011). According to the results of NFI8, the annual increment of forests is 0.76 billion $\mathrm{m}^{3}$ where the increments of survivor trees, harvested or dead trees, and ingrowth trees are $0.52,0.07$, and 0.17 billion $\mathrm{m}^{3}$, respectively. Looking at the results of previous NFIs, we find that the annual increment has gradually increased from 0.19 billion $\mathrm{m}^{3}$ in NFI1 to 0.76 billion $\mathrm{m}^{3}$ in NFI8. The main reason for this increase is probably the rapid development of plantations in China.

The drain estimated by China's NFI is defined as the volume of trees that were found to be harvested or dead between two inventory periods. The volume of the

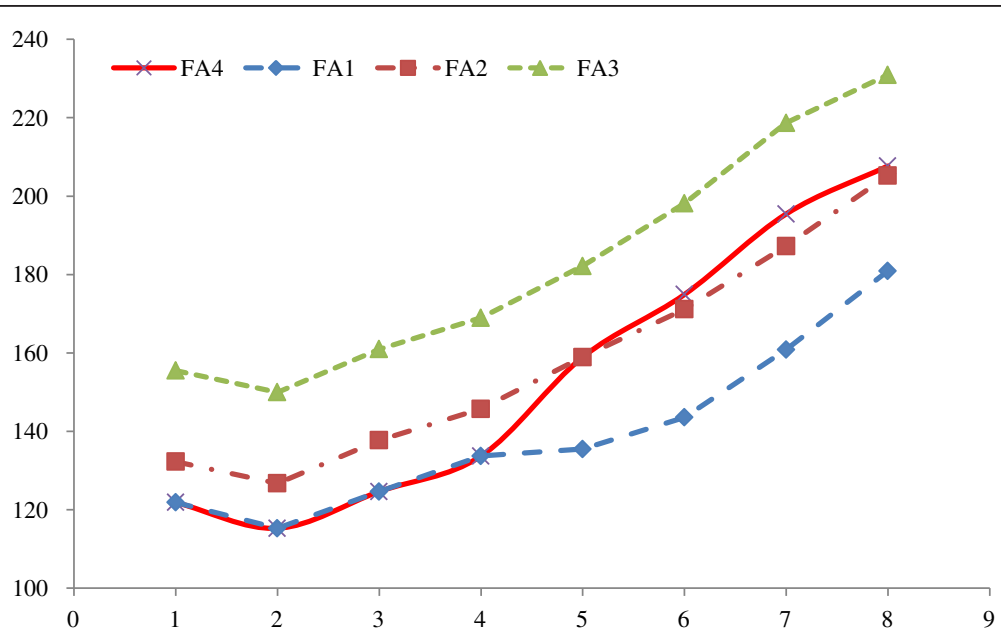

Fig. 1 Development of Forest Areas of the eight NFIs in China. (FA1—Forest areas only inclcuding $\geq 0.4$ (or $35 \%$ ) closed cover forests and economic shrubs; FA2 - Forest areas also including 0.2-0.3 (or 20-35\%) cover forests and economic shrubs; FA3-Forest areas including both $\geq 0.2$ (or $20 \%$ ) cover forests and all special shrubs (Wang and Hou 2014); FA4_Forest areas published in eight NFIs 
Table 5 The areas and proportions of forest categories from eight NFIs in China (Note: The forests in Taiwan, Hongkong and Macao are not included in this table)

\begin{tabular}{|c|c|c|c|c|c|c|c|c|c|c|c|c|}
\hline \multirow[t]{2}{*}{ NFIs } & \multicolumn{2}{|l|}{ Total } & \multicolumn{2}{|c|}{ Protection Forest } & \multicolumn{2}{|c|}{ Special-use forest } & \multicolumn{2}{|c|}{ Timber forest } & \multicolumn{2}{|c|}{ Fuelwood forest } & \multicolumn{2}{|c|}{ Economic forest } \\
\hline & Area & $\%$ & Area & $\%$ & Area & $\%$ & Area & $\%$ & Area & $\%$ & Area & $\%$ \\
\hline$\overline{\mathrm{NFI1}}$ & 119.78 & 100.00 & 7.85 & 6.55 & 0.67 & 0.56 & 99.07 & 82.71 & 3.67 & 3.07 & 8.52 & 7.11 \\
\hline $\mathrm{NFI} 2$ & 113.42 & 100.00 & 13.21 & 11.65 & 1.30 & 1.14 & 83.94 & 74.01 & 3.69 & 3.25 & 11.28 & 9.95 \\
\hline $\mathrm{NFI3}$ & 122.80 & 100.00 & 17.76 & 14.47 & 3.12 & 2.54 & 83.73 & 68.18 & 4.44 & 3.62 & 13.74 & 11.19 \\
\hline $\mathrm{NFI} 4$ & 131.85 & 100.00 & 19.28 & 14.62 & 3.35 & 2.54 & 88.83 & 67.38 & 4.29 & 3.25 & 16.10 & 12.21 \\
\hline $\mathrm{NFI5}$ & 156.84 & 100.00 & 24.59 & 15.68 & 3.97 & 2.53 & 103.61 & 66.06 & 4.45 & 2.84 & 20.22 & 12.89 \\
\hline NFI6 & 172.79 & 100.00 & 58.51 & 33.86 & 6.38 & 3.69 & 83.47 & 48.31 & 3.04 & 1.76 & 21.39 & 12.38 \\
\hline $\mathrm{NFI7}$ & 193.33 & 100.00 & 93.79 & 48.51 & 13.22 & 6.84 & 64.16 & 33.19 & 1.75 & 0.90 & 20.41 & 10.56 \\
\hline NFI8 & 205.56 & 100.00 & 99.67 & 48.49 & 16.31 & 7.93 & 67.24 & 32.71 & 1.77 & 0.86 & 20.57 & 10.01 \\
\hline
\end{tabular}

sample trees that have been cut or died between successive measurement occasions is calculated by using the tree measurements at the first occasion and adding half of estimated growth between measurements (SFA 2011). According to the results of NFI8, the annual drain is 0.51 billion $\mathrm{m}^{3}$ with the drains of harvested trees and dead trees being 0.39 and 0.12 billion $\mathrm{m}^{3}$. Comparing the results of previous NFIs, the annual drain gradually increased from 0.34 billion $\mathrm{m}^{3}$ in NFI3 (having no data about drain in NFI1 and NFI2) to 0.51 billion $\mathrm{m}^{3}$ in NFI8.

\section{Geographical distribution}

The forests in China are mainly distributed in the north-eastern, south-western and southern regions. About one half of the forest area is located in the 5 provinces Inner Mongolia, Heilongjiang, Yunnan, Sichuan, and Tibet (Fig. 2).

Less than $10 \%$ of the forest areas are distributed in the following 16 provinces (municipality, or autonomous region): Beijing, Tianjin, Hebei, Shanxi, Shanghai, Jiangsu, Anhui, Shandong, Henan, Haihan, Chongqing, Gansu, Qinghai, Ningxia, Honghong, and Macao. To simplify the analysis of change and distribution patterns, six regions have been identified for the whole country: the Northern,
North-Eastern, Eastern, South-Central, South-Western and North-Western region. Table 8 presents the forest areas and volumes of the six regions in eight NFIs.

Table 8 shows that the proportions of forest areas in the six regions are not very different except the lower proportion in north-western region. The developments of forest areas in the six regions are very similar corresponding to overall changes in the whole country, but the trends of forest area proportions are variable. The proportion of forest area in the north-eastern region decreased from $21 \%$ in the NFI1 to $16 \%$ in the NFI8, whereas the proportion in the north-wesertn region increased in recent decades from $6.6 \%$ in the NFI5 to $9.5 \%$ in the NFI8.

Similarly, Table 8 shows that the proportions of forest volumes in the six regions differ greatly. More than $40 \%$ of the total volume is found in the south-western region, with only about $1 / 3$ in the northern, eastern, southcentral and north-western regions. The proportion of forest volume in the north-eastern region decreased continuously from $25 \%$ in the NFI1 to $19 \%$ in the NFI8. The development of volumes in south-western region is similar to that in the north-eastern region. In contrast, the proportions of volumes in the eastern and south-central regions increased from 6 and $7 \%$ in the

Table 6 Areas and growing stock volumes of natural forests and plantations from eight NFIs in China

\begin{tabular}{|c|c|c|c|c|c|c|c|c|}
\hline \multirow[t]{2}{*}{ NFls } & \multicolumn{4}{|l|}{ Natural forests } & \multicolumn{4}{|l|}{ Plantations } \\
\hline & Area (million ha) & $\%$ & Volume (billion $\mathrm{m}^{3}$ ) & $\%$ & $\overline{\text { Area (million ha) }}$ & $\%$ & Volume (billion $\mathrm{m}^{3}$ ) & $\%$ \\
\hline NFI1 & 96.09 & 80.22 & 8.31 & 98.11 & 23.69 & 19.78 & 0.16 & 1.89 \\
\hline $\mathrm{NFI} 2$ & 91.12 & 80.42 & 8.53 & 96.93 & 22.19 & 19.58 & 0.27 & 3.07 \\
\hline $\mathrm{NFI3}$ & 91.67 & 74.72 & 8.38 & 94.05 & 31.01 & 25.28 & 0.53 & 5.95 \\
\hline NFI4 & 97.48 & 74.00 & 9.20 & 92.84 & 34.25 & 26.00 & 0.71 & 7.16 \\
\hline $\mathrm{NFI5}$ & 110.17 & 70.24 & 9.90 & 90.74 & 46.67 & 29.76 & 1.01 & 9.26 \\
\hline NFI6 & 115.76 & 68.49 & 10.59 & 87.52 & 53.26 & 31.51 & 1.51 & 12.48 \\
\hline $\mathrm{NFI7}$ & 119.69 & 65.99 & 11.40 & 85.33 & 61.69 & 34.01 & 1.96 & 14.67 \\
\hline NFI8 & 121.84 & 63.73 & 12.30 & 83.20 & 69.33 & 36.37 & 2.48 & 16.80 \\
\hline
\end{tabular}


Table 7 Areas and volumes of young and middle-aged forests and mature (including near-mature and over-mature) forests from eight NFIs in China

\begin{tabular}{|c|c|c|c|c|c|c|c|c|}
\hline \multirow[t]{2}{*}{ NFIs } & \multicolumn{4}{|c|}{ Young and middle-aged forests } & \multicolumn{4}{|l|}{ Mature forests } \\
\hline & $\overline{\text { Area (million ha) }}$ & $\%$ & Volume (billion $\mathrm{m}^{3}$ ) & $\%$ & $\overline{\text { Area (million ha) }}$ & $\%$ & Volume (billion $\mathrm{m}^{3}$ ) & $\%$ \\
\hline$\overline{\mathrm{NFI1}}$ & 70.68 & 64.14 & 2.49 & 28.75 & 39.51 & 35.86 & 6.17 & 71.25 \\
\hline $\mathrm{NFI} 2$ & 68.19 & 69.00 & 3.39 & 38.52 & 30.64 & 31.00 & 5.41 & 61.48 \\
\hline $\mathrm{NFI3}$ & 72.17 & 68.48 & 3.36 & 37.71 & 33.22 & 31.52 & 5.55 & 62.29 \\
\hline $\mathrm{NFI} 4$ & 77.84 & 69.60 & 3.71 & 37.44 & 34.00 & 30.40 & 6.20 & 62.56 \\
\hline NFI5 & 92.27 & 69.69 & 4.20 & 38.50 & 40.14 & 30.31 & 6.71 & 61.50 \\
\hline NFI6 & 96.88 & 67.85 & 4.71 & 38.93 & 45.91 & 32.15 & 7.39 & 61.07 \\
\hline NFI7 & 104.63 & 67.25 & 5.35 & 40.04 & 50.96 & 32.75 & 8.01 & 59.96 \\
\hline NFI8 & 106.43 & 64.66 & 5.74 & 38.84 & 58.17 & 35.34 & 9.04 & 61.16 \\
\hline
\end{tabular}

NFI1 to 11 and $12 \%$ in the NFI8 respectively while the volume proportions in the northern and north-western regions show little change.

\section{Discussion}

In reviewing the evolution of forest inventories in China, Europe, and the US through the 20th and 21st centuries, common themes emerge. Each of these inventories has shown movement toward: nationally consistent measure- ment; more efficient sample designs; implementation of improving technology; expansion of the variables monitored; and scientific transparency. Our focus below is how China's expanding NFI exemplifies these global trends.

\section{Nationally consistent measurement}

Initial inventory efforts are almost necessarily local, using methods appropriate for meeting specific information needs. As national-scale resource assessment has

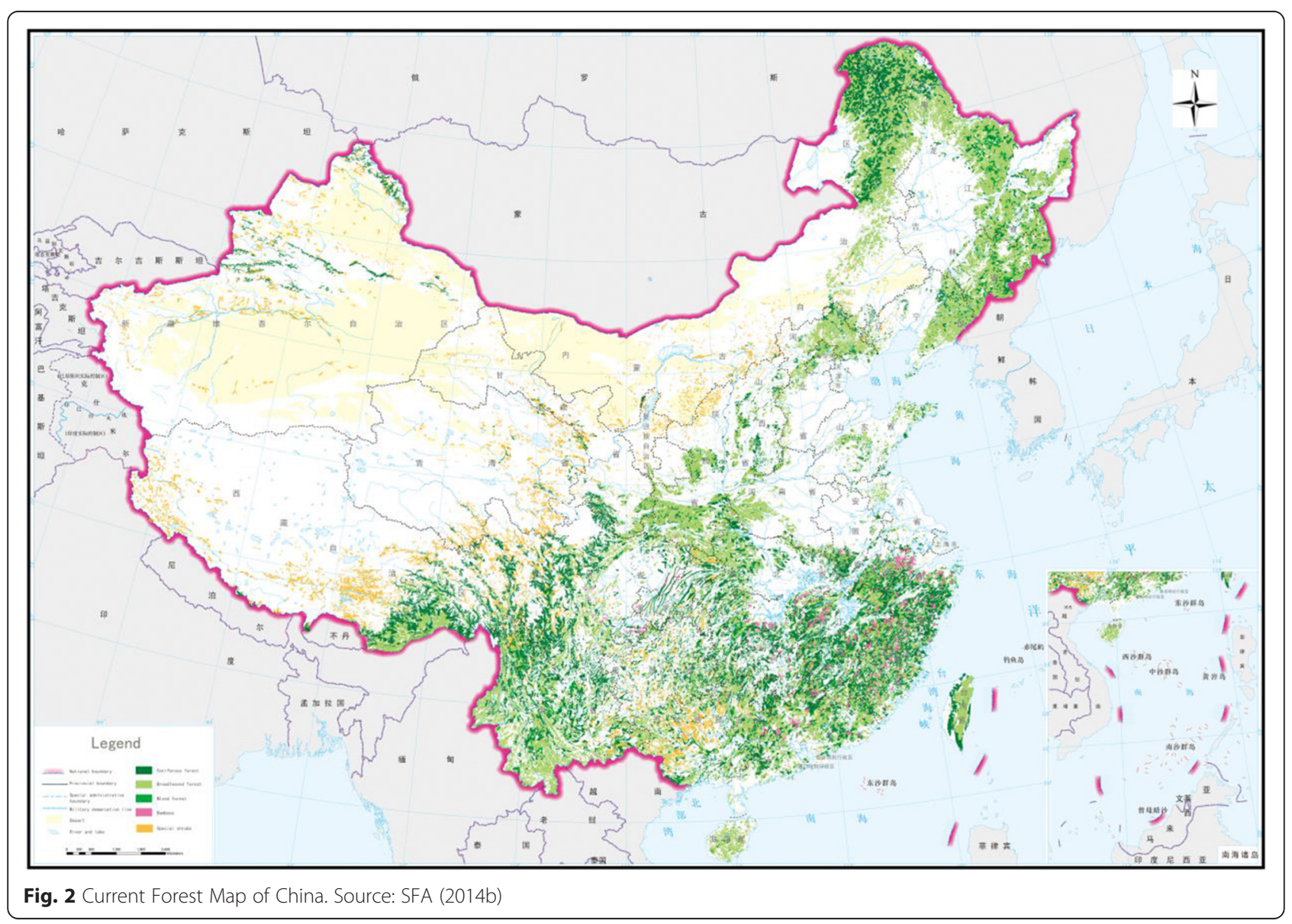


Table 8 Forest areas and volumes of the six regions in eight NFIs

\begin{tabular}{|c|c|c|c|c|c|c|c|c|}
\hline Regions & NFI1 & $\mathrm{NFI} 2$ & $\mathrm{NFI3}$ & $\mathrm{NFI} 4$ & $\mathrm{NFI5}$ & NFI6 & $\mathrm{NFI7}$ & $\mathrm{NFI} 8$ \\
\hline \multicolumn{9}{|c|}{ Forest areas (million ha) } \\
\hline Total & 119.78 & 113.31 & 122.68 & 131.73 & 156.84 & 172.79 & 193.33 & 205.56 \\
\hline NO & 15.43 & 16.40 & 17.12 & 18.17 & 20.37 & 23.29 & 27.61 & 29.74 \\
\hline NE & 25.16 & 25.02 & 25.79 & 26.43 & 29.18 & 29.85 & 31.63 & 32.71 \\
\hline EA & 19.39 & 16.42 & 19.29 & 21.56 & 26.99 & 28.65 & 30.51 & 32.07 \\
\hline SC & 25.72 & 23.18 & 23.14 & 26.28 & 32.83 & 36.04 & 40.03 & 42.46 \\
\hline SW & 25.90 & 24.64 & 28.74 & 30.71 & 37.14 & 42.39 & 46.31 & 49.06 \\
\hline NW & 8.18 & 7.65 & 8.62 & 8.58 & 10.33 & 12.57 & 17.24 & 19.52 \\
\hline \multicolumn{9}{|c|}{ Forest volumes (billion $\mathrm{m}^{3}$ ) } \\
\hline Total & 84.70 & 88.01 & 89.14 & 99.10 & 109.08 & 120.98 & 133.63 & 147.79 \\
\hline NO & 8.75 & 9.09 & 9.51 & 10.00 & 11.06 & 12.39 & 13.50 & 15.68 \\
\hline NE & 21.33 & 21.94 & 21.48 & 22.41 & 23.59 & 23.66 & 25.68 & 28.18 \\
\hline EA & 5.39 & 6.74 & 6.10 & 6.83 & 8.06 & 10.43 & 12.89 & 15.70 \\
\hline SC & 5.94 & 7.15 & 6.78 & 7.52 & 9.24 & 12.24 & 15.31 & 17.44 \\
\hline SW & 36.78 & 36.73 & 38.78 & 45.59 & 49.46 & 54.23 & 57.48 & 60.82 \\
\hline NW & 6.51 & 6.36 & 6.49 & 6.75 & 7.67 & 8.03 & 8.77 & 9.97 \\
\hline
\end{tabular}

NO northern region, including Beijing, Tianjin, Hebei, Shanxi, and Inner Mongolia, NE north-eastern region, including Liaoning, Jilin, and Heilongjiang, EA eastern region, including Shanghai, Jiangsu, Zhejiang, Anhui, Fujian, Jangxi, and Shandong, SC south-central region, including Henan, Hubei, Hunan, Guangdong, Guangxi, and Hainan, SW south-western region, including Chongqing, Sichuan, Guizhou, Yunan, and Tibet, NW north-western region, including Shaanxi, Gansu, Qinghai, Ningxia, and Xinjiang. The forests in Taiwan, Honghong and Macao are not included in this table

become a priority in the countries we have surveyed, the need for consistent measurement standards has become apparent. Standards often originate from influential pilot studies or through lessons learned by sub-national or international inventories. In China, the continuous forest inventory (CFI) pilot in Jiangxi province strongly influenced standards, beginning with the second NFI (19771981). Sampling strategies were tested and validated through the Jiangxi pilot application. Later, remote sensing and GPS techniques now used in China's NFI were also first applied in Jiangxi. International collaboration affected the volution of forest inventory strategies. One example is the use of permanent sample plots in a statistically sound way (e.g., Matérn 1984).

Regional differences in inventory methods still do exist. For example, plot design varies widely within the country. However, the NFI performs the central function of integrating regional inventory methods by, for example, developing standard classification methods that are compatible with the measurements made in constituent regions. China's capacity to coherently report national forest resources across a wide range of ecosystems has depended upon convergence toward consistent methodologies, and this trend will likely continue. Note also that a cost-efficient inventory may require different sampling intensities in different ecozones. The most important aspect is that the estimates within a country and between countries are comparable.

\section{More efficient sample designs}

National forest inventories are charged with monitoring large areas with limited budgets. Our survey of international inventories suggests that improvements to plot and sample designs are made in the interests of obtaining better estimate precision without requiring additional field costs. Plot designs evolve as more efficient measurement configurations are shown to adequately capture local conditions, while new sample designs are developed to improve variance estimates by controlling how plots are distributed or analyzed. A "statistical" design based framework has been used in most inventories. Systematic or stratified systematic sampling designs are often used and three-stage design in US. Arranging plots into clusters is also common particularly in Europe, a cluster aiming to be a one-day workload on average. The FIA in USA uses detached plots. A circular plot is the most common plot design, with either one radius or a few radii. Angle count plot is used by some countries.

Through the 1950s and 60s, China's developing capacity to carry out forest inventory was dependent upon methods that were heterogeneous across counties. Pilot studies in the 1970s led to establishment of continuous forest inventory principles that have since influenced sample design parameters nationally. While plot size, orientation, and remeasurement cycle varies by province, permanent plots are now standard across the country. The concept of unbiased plot distribution is standard, too, with simple random 
designs used in some provinces and stratified designs used in others. With more and more application of high resolution remote sensing, it is possible to improve the sampling design of the Chinese NFI, for example with reference to the annual inventory system in the US, allowing more immediate response of inventory results to broad-scale disturbances or trends.

\section{Implementation of improving technology}

New technology has affected how national forest inventories get to, measure, store, and analyze plot information. Just as basal area prisms enabled advances in decades past to efficiency of plot data collection, new technologies are influencing how China assembles its inventory estimates. Remote sensing has been used as the primary measurement of forest area in inaccessible regions, and is currently used to develop estimation strata in some provinces. Global positioning greatly facilitates the navigation needed to re-measure the permanent plots now used throughout the country, and use of PDAs has reduced time and human error associated with data input.

New modeling techniques have improved tree-level estimation of variables such as volume and biomass, and have more recently been used to estimate growth, mortality, biomass and carbon storage (Ge et al. 2004; Li and Lei 2010). Finally, the use of GIS has improved how inventory data are stored, queried, and applied to the production of resource maps (Wang and Li 2010).

\section{Expansion of variables studied}

China's early inventory efforts, like those throughout the world at the time, focused on the timber supply. In China, as elsewhere, a growing appreciation of the ecosystem services and non-timber forest products provided by forests has created a need for broader assessment capacities. Beginning with NFI7 (2004-2008), a suite of environmental variables has been added to the inventory to support assessment of ecosystem services (Table 1). This has enabled new assessments of both ecological services (Dai et al. 2009) and forest health (Yang et al. 2015). Like the rest of the world, China continues to develop better biomass equations so that climate change mitigation function of forest carbon storage may be better understood (Zeng 2014).

\section{Scientific transparency}

As national forest inventory data are being used in a wider array of scientific inquiries, users need to understand the properties and limitations of the sample. As inventories have matured, methodology increasingly is both influenced and vetted by the international scientific community, a process which ensures rigour and provides documentation for the user community. This paper and other recent works (Yan et al. 2011; Zeng 2013) contribute to peer understanding of Chinese methods. FAO and other projects, such COST Action E43 have done great work in adopting common definitions worldwide, a process which relies upon clear methodological description from cooperating countries (COST Action E43 2015).

Recent increases in Chinese forest area and growing stock have resulted from huge afforestation and reforestation efforts. It is important both within and outside of the country to understand methodological details used to verify these increases. It is also essential to see the extensive efforts, detailed here (Fig. 1), that have gone into reconciling changes to the inventory in the interests of making estimates that are consistent over time. A next step in the process of transparency might be the public access to the plot-level observations themselves. In addition to providing users more context about how estimates are made, public access would likely stimulate important ties to remotely sensed data as well as new analyses at more local levels.

\section{Conclusions}

This paper documents important changes in the Chinese NFI both to support continued trend analysis and to apprise data users of important changes to the inventory over the years. Critical details about sample design and plot design are likewise given, and uses of other data sources are described. New technologies and data needs ensure that the Chinese inventory, like the inventories in other countries, will continue to evolve. With historical changes and current conditions as context, we have suggested likely directions for this evolution.

\section{Competing interests}

The authors declare that they have no competing interests.

\section{Authors' contributions}

WeiSheng Zeng carried out the second and third sections about the NFI in China and the results. Erkki Tomppo carried out the first section National Forest Inventories and participated in the fourth section Discussion. Sean Healty carried out the Discussion and participated in the first section. Klaus Gadow drafted the outline of the manuscript, and participated in the first and Discussion sections. All authors read and approved the final manuscript.

\section{Acknowledgements}

The authors thank Ms Yang XueYun of the Academy of Forest Inventory and Planning, State Forestry Administration (Beijing), for compiling the main results of previous NFIs in China.

\section{Author details}

${ }^{1}$ Academy of Forest Inventory and Planning, State Forestry Administration, Beijing 100714, China. ${ }^{2}$ Natural Resources Institute Finland, Helsinki, Finland. ${ }^{3}$ Forest Service, United States Department of Agriculture, Ogden, UT, USA.

${ }^{4}$ University of Göttingen, Göttingen, Germany. ${ }^{5}$ Beijing Forestry University, Beijing, China. ${ }^{6}$ Department of Forestry and Wood Technology, University of Stellenbosch, Stellenbosch, South Africa.

Received: 20 June 2015 Accepted: 22 July 2015

Published online: 04 August 2015

\section{References}

AFM (1978) Specifications on continuous forest inventory in China. Agriculture and Forestry Ministry, People's Republic of China, p 18 
Axelsson A-L, Ståhl G, Söderberg U, Petersson H, Fridman J, Lundström A (2010) Sweden. In: Tomppo E, Gschwantner TH, Lawrence M, McRoberts RE (eds) National forest inventories-pathways for common reporting. Springer., pp 19-32, ISBN 978-90-481-3232-4

Bolsinger CL, Waddell KL (1993) Area of old-growth forests in California, Oregon, and Washington. U.F.S.P.N.R. Station, Portland, OR, p 26

Cen JY, Li QY, Zeng WS, Li XM (2007) Assessment of continuous forest inventory system in Guangxi. Central South Forest Inventory and Planning 26(3):8-13

COST Action E43 (2015) Harmonisation of national forest inventories in Europe: techniques for common reporting., http://www.metla.fi/eu/cost/e43/. Last accessed. May 18, 2015

Dai L, Zhao F, Shao G, Zhou L, Tang L (2009) China's classification-based forest management: procedures, problems, and prospects. Environ Manag 43:1162-1173

Davis LS, Johnson KN, Bettinger P, Howard TE (2001) Forest management to sustain ecological, economic, and social values, 4th edn. Waveland Press, Inc, Long Grove, IL, ISBN 1-57766-436-1

FAO (2013) Support to forest monitoring and assessment, country projects [online]., Available from www.fao.org/forestry/fma/73410/en/ [accessed 26 May2015]

Ge HL, Meng XY, Tang XM (2004) Growth model system for continuous forest inventory. For Res 17(4):413-419 (In Chinese)

Grosenbaugh LR (1958) Point-sampling and line-sampling: probability theory, geometric implications, synthesis. In: F.S. U.S. Department of Agriculture (ed) Southern forest experimental station., p 34

Healey SP, Lapoint E, Moisen GG, Powell SL (2011) Maintaining the confidentiality of plot locations by exploiting the low sensitivity of forest structure models to different spectral extraction kernels. Int J Remote Sens 32:287-297

Ilvessalo Y (1927) The forests of Suomi (Finland). Results of the general survey of the forests of the country carried out during the years 1921-1924. Communicationes Ex Instituto Quaestionum Forestalium Finlandiae. Editae 11

IPCC (2015) Fifth Assessment Report (AR5)., http://www.ipcc.ch/pdf/assessment-report/ ar5/syr/AR5_SYR_FINAL_SPM.pdf (retrieved 30th May, 2015)

Koch B (2013) Remote sensing supporting national forest inventories. In: FAO knowledge reference for national forest assessments., http://forestportal.efi. int/lists.php?pl=01\&sf=1

Labau VJ, Bones JT, Kingsley NP, Lund HG, Smith WB (1992) A history of the forest survey in the United States: 1830-2004. F.S. U.S. Department of Agriculture, Washington DC, p 82

Lanz A, Alberdi I, Barbati A, Barsoum N, Brändli U-B, Chirici G, Cienciala E, Condés S, Di Cosmo L, Freudenschuss A, Gabler K, Gschwantner T, Hylen G, Ilvesniemi H, Kusar G, Kändler G, Lawrence M, McRoberts RE, Nabuurs G-J, Petersson H, Priwitzer T, Robert N, Rondeux J, Schadauer K, Ståhl G, Tomter S, Tomppo E, Tosi V, Vidal C, Weiss P. Winter S (2010) Harmonisation of national forest inventories in Europe. Reference definitions. In: Tomppo E, Gschwantner TH, Lawrence M, McRoberts RE (eds) National forest inventories-pathways for common reporting. Springer., pp 1-18, ISBN 978-90-481-3232-4

Lawrence M, McRoberts RE, Tomppo E, Gschwantner Th, Gabler K (2010) Comparisons of National Forest Inventories. In: Tomppo E, Gschwantner Th, Lawrence M, McRoberts RE (eds.). National Forest Inventories - Pathways for common reporting. Springer, p. 19-32. ISBN 978-90-481-3232-4.

Lei JF (2005) Forest resources in China. Chinese Forestry Press, Beijing, p 408

Lei XD, Tang MP, Lu YC, Hong LX, Tian DL (2009) Forest inventory in China: status and challenges. Int For Rev 11(1):52-63

Li HK, Lei YC (2010) Estimation of forest biomass carbon storage in China. Chinese Standard Press, Beijing, p 60

Lin GZ, Wen XR, Zhou CG, She GH (2013) Review and progress of China's continuous forest inventory system. Open J For 3(1):17-22

Loetsch F, Haller KE (1973) Forest inventory. Vol I. BLV Verlagsgesellschaft mbH, München

Luo HB, Chen XQ, Zhou GH, Yu S, Zeng WS (2002) Benefit analysis to application of GPS positioning technique in continuous forest inventory of Tibet. Central South Forest Inventory and Planning 21(1):25-26

Matérn B (1984) Four lectures on forest biometry. Report 23. Swedish University of Agricultural Sciences. Section of Forest Biometry. Umeå. Sweden., ISBN 91-576-2001-6

McRoberts RE (2012) Estimating forest attribute parameters for small areas using nearest neighbors techniques. For Ecol Manag 272:3-12

McRoberts RE, Tomppo EO (2007) Remote sensing support for national forest inventories. Remote Sens Environ 110:412-419

McRoberts RE, Nelson MD, Wendt DG (2002) Stratified estimation of forest area using satellite imagery, inventory data, and the k-Nearest Neighbors technique. Remote Sens Environ 82:457-468
McRoberts RE, Tomppo EO, Vibrans AC, de Freitas JV (2013) Design considerations for tropical forest inventories. Pesquisa Florestal Brasileira-Brazilian Journal of Forestry Research 33(74):189-202

Reams GA, Smith WD, Hansen MH, Bechtold WA, Roesch FA, Moisen GG (2005) The forest inventory and analysis sampling frame. In: Bechtold WA, Patterson $\mathrm{PL}$ (eds) The enhanced forest inventory and analysis program-national sampling design and estimation procedures. US Forest Service Southern Research Station, Asheville, NC

Reese $H$, Nilsson M, Pahén TG, Hagner O, Joyce S, Tingelöf U, Egberth M, Olsson $H$ (2003) Countrywide estimates of forest variables using satellite data and field data from the National Forest Inventory. Ambio 32:542-548

Saket M, Branthomme A, Piazza M (2010) FAO NFMA—support to developing countries on national forest monitoring and assessment. In: Tomppo $E_{\text {, }}$ Gschwantner TH, Lawrence M, McRoberts RE (eds) National forest inventories_-pathways for common reporting. Edited by Springer., pp 583-594

SFA (2009) Report of forest resources in China (2004-2008). China Forestry Press, Beijing, p 68

SFA (2011) Specification for data processing and statistic in national forest inventory (LY/T 1957). Chinese Standard Press, Beijing, p 50

SFA (2014a) Technical specifications on national continuous forest inventory

SFA (2014b) Report of forest resources in China (2009-2013). China Forestry Press, Beijing, p 86

Shu J (2014) Application of geographical information system (GIS) in China's forestry. Inner Mongolia Forestry Investigation and Design 37(3):59-61

Smith WB, Miles PD, Perry CH, Pugh SA (2009) Forest resources of the United States, 2007. F.S. U.S. Department of Agriculture, Washington DC, p 336

Spurr SH (1960) Photogrammetry and photo-interpretation, 2nd edn. The Ronald Press Company, New York

Ståhl G, Cienciala E, Chinci G, Lanz A, Vidal C, Winter S, McRoberts RE, Rondeux J, Schadauer K, Tomppo E (2012) Bridging national and reference definitions for harmonizing forest statistics. For Sci 58(3):214-223

Tomppo E, Katila M (2008) Comparing alternative sampling designs for national and regional forest monitoring. In: Tomppo E, Andersson K (eds) Technical review of FAO's approach and methods for National Forest Monitoring and Assessment (NFMA), FAO, NFMA working paper $38 .$, pp 55-86, Available from www.fao.org/docrep/016/ap153e/ap153e.pdf [accessed 26 May 2015]

Tomppo E, Haakana M, Katila M, Peräsaari J (2008) Multi-source national forest inventory-methods and applications. Managing forest ecosystems 18. Springer., p 374, ISBN 978-1-4020-8712.-7

Tomppo E, Gschwantner T, Lawrence M, McRoberts RE (eds) (2010a) National forest inventories: pathways for common reporting. Springer, New York, USA, pp 113-130

Tomppo E, Schadauer K, McRoberts RE, Gschwantner TH, Gabler K, Ståhl G (2010b) Introduction. In: Tomppo E, Gschwantner TH, Lawrence M, McRoberts RE (eds) National forest inventories-pathways for common reporting. Springer., pp 1-18, ISBN 978-90-481-3232-4

Tomppo E, Heikkinen J, Henttonen HM, Ihalainen A, Katila M, Mäkelä H, Tuomainen T, Vainikainen N (2011) Designing and conducting a forest inventory-case: 9th national forest inventory of Finland. Springer, Managing forest ecosystems 21., p 270, ISBN 978-94-007-1651-3

Tomppo E, Malimbwi R, Katila M, Mäkisara K, Henttonen HM, Chamuya N, Zahabu E, Otieno J (2014) A sampling design for a large area forest inventory: case Tanzania. Can J For Res 44(2014):931-948

Tomter ST, Hylen G, Nilsen J-E (2010) Norway. In: Tomppo E, Gschwantner TH, Lawrence M, McRoberts RE (eds) National forest inventories-pathways for common reporting. Springer., pp 19-32, ISBN 978-90-481-3232-4

U.S. Department of Agriculture, F.S. (1965) Timber trends in the United States. F.S. U.S. Department of Agriculture, Washington Office, p 713

U.S. Department of Agriculture, F.S. (1992) Forest service resource inventories: an overview. USDA, Washington, DC, p 39

U.S. Department of Agriculture, F.S. (2015) The forest inventory and analysis strategic plan. USDA, Washington, DC, p 40

Wang XK (2006) Application of PDA in forest resources inventory. Shanxi Forestry Science \& Technology 2:34-36

Wang XK, Hou XW (2014) The special shrub resources in China. For Res Manage S0:13-16

Wang LR, Li CG (2010) Developing of a mobile GIS system of digital forest resource continuous inventory. Scientia Silvae Sinicae 46(8):174-175

Wang XJ, Han AH, Huang GS, Zhang YX, Ding XQ (2005) Establishment of a national RS-based forest resources monitoring operational system. For Res Manage 2:70-74 
Wu HG, Jiang LY (2006) Some measures to improve the precision and application level of GPS in forestry. For Res Manage 2:46-50

Xiao XW (2005) National forest inventory of China. China Forestry Press, Beijing, p 282

Xiao ZH, Xue CQ, Xiong ZP, Liu KC (2013) National integrated monitoring for

forest resources and ecological situations in 2012: a pilot study in

Guangdong. China Forestry Press, Beijing, p 130

Yan HW, Huang GS, Zeng WS, Nie XY, Gao XL (2011) Considerations on construction of the integrated forest resource monitoring system in China. For Res Manage 6:6-11

Yang J, Dai GH, Wang SR (2015) China's national monitoring program on ecological functions of forests: an analysis of the protocol and initial results. Forests 6:809-826

Zeng WS (2004) Discussion on application of remote sensing in forest inventories. Central South Forest Inventory and Planning 23(1):47-49

Zeng WS (2011) Methodology on modeling of single-tree biomass equations for national biomass estimation in China. Dissertation. Chinese Academy of Forestry, Beijing

Zeng WS (2013) Discussion on methods for producing annual national estimates of forest resources. For Res Manage 1:26-31

Zeng WS (2014) Development of monitoring and assessment of forest biomass and carbon storage in China. Forest Ecosystems 1:20

Zeng WS (2015) Using nonlinear mixed model and dummy variable model approaches to construct origin-based single tree biomass equations. Trees 29(1):275-283

Zhang YX, Wang ZX (2007) Research on application of remote sensing in forest inventory. China Forestry Press, Beijing, p 170

Zhang HJ, Zhang J (2008) Using PDA and " $3 S^{\text {" }}$ tecnniques to achieve paper-free data collection in forest inventory. Forestry Engineering 24(3):39-40

\section{Submit your manuscript to a SpringerOpen ${ }^{\circ}$} journal and benefit from:

- Convenient online submission

- Rigorous peer review

- Immediate publication on acceptance

- Open access: articles freely available online

- High visibility within the field

- Retaining the copyright to your article

Submit your next manuscript at $>$ springeropen.com 